\title{
FAKTOR-FAKTOR YANG MEMENGARUHI NEUROPATI PERIFER TERKAIT HIV DI MANADO
}

\author{
FACTORS THAT INFLUENCE HIV ASSOCIATED PERIPHERAL \\ NEUROPATHY IN MANADO \\ Deivy Cirayow, * Arthur Hendrik Philips Mawuntu, * Herlyani Khosama*
}

\section{ABSTRACT}

Introduction: There are several sociodemographic and clinical factors that influence the development of HIV associated peripheral neuropathy (HIV-PN). Manado has different sociodemographic and clinical characteristics from other regions. However, the percentage of HIV-PN and its influencing factors are unknown.

Aims: To know the percentage of HIV-PN and factors that influence this disorder in Manado.

Methods: A crosssectional study conducted in HIV/AIDS clinic R.D. Kandou hospital Manado between November 2016-January 2017. Neuropathy evaluation was performed using brief peripheral neuropathy screening (BPNS), neuropathic pain diagnostic questionnaire (DN4), and electroneurography. A Chi-square or Fisher exact test was done to analyze categorical variables, independent Tor Mann-Whitney test was done for numerical variables, and linear regression was done in multivariate analysis.

Results: 50 subjects were included, most were male (70\%), and the mean age was 32.98 ( \pm 9.726$)$ years, with HIV$N P$ percentage was $46 \%$. Age $>30$ years old, low hemoglobin count, CD4, and low international HIV dementia scale (IHDS) significantly associated with HIV-NP. Working subjects were 13.6 times more likely to have HIV-PN.

Discussion: HIV-PN prevalence was relatively high, influenced by age $>30$ years old an low hemoglobin, CD4, and IHDS. As a factor, working was escalating the likelihood of NP-HIV by 13.9 times.

Keywords: HIV/AIDS, influencing factors, peripheral neuropathy

\section{ABSTRAK}

Pendahuluan: Neuropati perifer terkait human immunodeficiency virus/HIV (NP-HIV) dapat dipengaruhi oleh beberapa faktor klinis dan sosiodemografis. Manado mempunyai karakteristik yang berbeda dengan daerah lain, namun belum diketahui persentase NP-HIV dan faktor-faktor yang memengaruhinya.

Tujuan: Mengetahui persentase NP-HIV dan faktor-faktor yang memengaruhinya di Manado.

Metode: Penelitian potong lintang terhadap pasien HIV/AIDS di poliklinik HIV/AIDS RSUP Prof. dr. R.D. Kandou, Manado, pada November 2016-Januari 2017. Evaluasi neuropati dilakukan menggunakan brief peripheral neuropathy screening (BPNS), neuropathic pain diagnostic questionnaire (DN4), dan elektroneurografi. Digunakan uji Chi-square atau Fisher exact untuk menganalisis variabel kategorik, uji T independen atau Mann-Whitney untuk variabel numerik, dan regresi linear untuk analisis multivariat.

Hasil: Didapatkan 50 subjek yang memenuhi kriteria penelitian dengan mayoritas laki-laki $(70 \%)$, rerata usia $32,98 \pm 9,726$ tahun, dan mengalami NP-HIV sebanyak $46 \%$. Usia $>30$ tahun, kadar hemoglobin, jumlah CD4, dan skor international HIV dementia scale (IHDS) yang rendah berhubungan secara bermakna dengan adanya NP-HIV. Adapun subjek yang bekerja berisiko 13,6 kali lebih besar mengalami NP-HIV.

Diskusi: Didapatkan prevalensi NP-HIV yang cukup tinggi dengan dipengaruhi oleh usia $>30$ tahun serta kadar hemoglobin, CD4, dan skor IHDS yang rendah. Faktor bekerja juga meningkatkan kecenderungan 13,9 kali mengalami NP terkait HIV.

Kata kunci: Faktor-faktor yang memengaruhi, HIV/AIDS, neuropati perifer

*Bagian/KSM Neurologi FK Universitas Sam Ratulangi/RSUP Prof. Dr. R.D. Kandou, Manado. Korespondensi: deivy_cirayow@ yahoo.com.

\section{PENDAHULUAN}

Neuropati perifer (NP) adalah gangguan atau lesi saraf tepi dengan etiopatologi yang bervariasi. Gangguan ini merupakan penyulit infeksi human immunodeficiency virus (HIV) atau acquired immunodeficiency syndrome (AIDS) yang paling umum ditemui. Prevalensinya diperkirakan sekitar $19-42 \%$ di seluruh dunia yang berperan terhadap penurunan kualitas hidup pasien. ${ }^{1-2}$

Neuropati perifer terkait HIV (NP-HIV) dapat berupa tipe motorik maupun sensorik, namun yang paling sering adalah neuropati sensorik. Timbulnya 
NP pada pasien HIV berhubungan dengan waktu lamanya terinfeksi HIV dan penggunaan obat antiretrovirus (ARV). Namun demikian, timbulnya NP juga berhubungan dengan stadium klinis infeksi HIV, jumlah limfosit cluster of differentiation 4 (CD4), tingginya viral load HIV, adanya infeksi oportunistik, ${ }^{1-3}$ serta obat-obat ARV yang neurotoksik seperti stavudine dan zidovudine. Demikian pula perlu ditatalaksana faktor lain yang turut memperberat neuropati, seperti diabetes melitus, defisiensi vitamin, dan penyalahgunaan alkohol. ${ }^{3-4}$

Pemeriksaan yang dikerjakan untuk mendiagnosis NP terkait HIV mencakup pemeriksaan invasif seperti biopsi dan noninvasif seperti pemeriksaan elektroneurografi (ENG) dan uji saring klinis. Biopsi tidak rutin dilakukan. Jika dilakukan, maka penanda patologis utama adalah degenerasi aksonal distal, hilangnya neuron di ganglion radiks dorsalis dari saraf yang terkena, dan infiltrasi sel-sel radang pada biopsi saraf serta penurunan densitas serabut saraf epidermis (epidermal nerve fiber/ EDNF) pada biopsi kulit. ${ }^{1-2,5-6}$

Pemeriksaan ENG tidak selalu dikerjakan untuk menegakkan diagnosis NP terkait HIV, namun bermanfaat untuk menyingkirkan diagnosis banding. Adapun uji saring yang sering digunakan adalah suatu sistem skor brief peripheral neuropathy screening/BPNS). Uji ini telah divalidasi oleh AIDS Clinical Trial Group (ACTG) serta praktis dan tidak mahal. Diagnosis neuropati perifer bila ditemukan $\geq 1$ gejala yang dalam kuesioner BPNS dan satu dari tanda berikut: penurunan refleks tendon Achilles atau penurunan sensibilitas vibrasi ibu jari kaki. Pasien dengan dua tanda abnormal tetapi tidak mengeluhkan gejala tidak terdiagnosis sebagai NP. Hal ini juga mungkin yang menyebabkan besarnya variasi prevalensi NP terkait HIV dari berbagai penelitian yang menggunakan uji ini. Beberapa peneliti menganggap kelompok ini sebagai NP asimtomatik atau masih tahap awal yang bisa menjadi simtomatik.

Ellis dkk mendefinisikan NP jika ditemukan penurunan refleks tendon Achilles di kedua kaki atau penurunan sensibilitas vibrasi di kedua kaki. Hasilnya sensitivitas meningkat hingga $80 \%$, namun spesifisitas menurun menjadi 59\%., ${ }^{2,5,7}$ Sensitivitas BPNS cukup rendah yaitu sekitar $49 \%$ dibandingkan standar referensi, yaitu skor neuropati total yang dimodifikasi (modified total neuropathyscore/mTNS). Dengan demikian tetap perlu dilakukan pemeriksaan tambahan lain guna meningkatkan sensitivitasnya. ${ }^{7}$

Neuropathic pain diagnostic questionnaire (DN4) adalah salah satu alat bantu pengukuran untuk menentukan adanya nyeri neuropati. Pengukuran dengan DN4 hanya menggunakan gabungan antara anamnesis dengan pemeriksaan disfungsi sensorik, sehingga mudah untuk dikerjakan dan sederhana. Uji ini juga mungkin merupakan alat bantu pengukuran paling baik untuk membedakan nyeri neuropati dengan nyeri nosiseptif. ${ }^{2}$

Jumlah kumulatif kasus infeksi HIV dan AIDS di Indonesia dari tahun 1987 hingga 2014 adalah 206.095 kasus, sebanyak 3110 kasus terdapat di Sulawesi Utara. ${ }^{8}$ Hal ini menempatkan Sulawesi Utara kedua terbanyak di daerah Sulawesi dan Maluku, termasuk angka NP terkait HIV, sehingga perlu diteliti lebih lanjut.

Kelompok usia 20-40 tahun adalah kelompok usia dengan persentase pasien HIV/AIDS tertinggi. Kelompok tersebut merupakan kelompok usia produktif. Adanya gejala neuropati tentu sangat membatasi aktivitas kerja dan produktivitas. Konsekuensi sosial ekonomi dari masalah ini akan mengenai pribadi, keluarga, dan negara..$^{8-9}$

Pelayanan HIV/AIDS sudah dibuka di RSUP Prof. Dr. R.D. Kandou, Manado tahun 2004, sedangkan Kelompok Staf Medis (KSM) Neurologi mulai banyak berperan dalam perawatan pasien sejak tahun 2010. Meskipun demikian, sampai saat ini belum diketahui faktor-faktor yang memengaruhi NP pada pasien HIV di Manado, juga belum banyak dilakukan di Indonesia. Padahal hal ini sangat penting karena memengaruhi kebijakan terapi termasuk penggunaan ARV serta kualitas hidup pasien.

\section{TUJUAN}

Mengetahui karakteristik klinis NP-HIV faktor-faktor yang memengaruhi di Manado.

\section{METODE}

Penelitian potong lintang terhadap pasien HIV/ AIDS berusia lebih dari 18 tahun yang berobat ke Poliklinik HIV/AIDS di RSUP Prof. Dr. R.D. Kandou, Manado secara konsekutif pada bulan November 
2016 hingga Januari 2017. Kriteria eksklusi adalah memiliki riwayat penyakit sistemik berupa diabetes melitus, penyakit kelenjar tiroid, gagal ginjal/uremia, dan keganasan dengan/tanpa riwayat mendapat kemoterapi, mengonsumsi obat-obat kemoterapi, statin, amiodaron, dan takrolimus selama lebih dari tujuh hari; memiliki pekerjaan dengan penggunaan tangan/lengan secara repetitif atau bertenaga seperti pekerja kasar/buruh kasar yang dapat mengganggu pemeriksaan; memiliki kelainan bawaan atau pernah mengalami patah tulang atau cedera lainnya pada lengan dan tungkai; memiliki riwayat penyakit rematik atau penyakit sendi degeneratif pada lengan atau tungkai; adanya penyakit vaskular perifer; memiliki gejala klinis mielopati dan radikulopati; serta pasien dengan gangguan jiwa atau pasien yang tidak kooperatif.

Evaluasi neuropati dilakukan dengan menggunakan BPNS dan DN4 yang sudah tervalidasi dalam bahasa Indonesia, ${ }^{1-2}$ serta pemeriksaan ENG secara berurutan dengan interval waktu 30 menit. Subjek dinyatakan menderita NP-HIV bila terdapat hasil positif pada uji BPNS dan atau DN4 dan atau ENG. Dilakukan juga pemeriksaan International HIV Dementia Scale (IHDS) sebagai uji penyaring demensia HIV yang. Pemeriksaan ini mudah dan lazim dipergunakan di banyak negara, serta memiliki sensitivitas $80 \%$ dan spesifisitas $55-57 \% .^{10}$ Diambil batas nilai untuk gangguan kognitif jika skor IHDS $\leq 10$.

Analisis bivariat variabel kategorik yang dikerjakan adalah uji Chi-square untuk data yang terdistribusi normal dan uji Fisher exact untuk data yang tidak terdistribusi normal. Normalitas distribusi variabel numerik diperiksa dengan uji Shapiro-Wilk. Untuk variabel yang terdistribusi normal dianalisis dengan uji $\mathrm{T}$ independen dan yang tidak normal diuji dengan uji Mann-Whitney. Analisis multivariat yang dikerjakan adalah regresi logistik dengan nilai $\mathrm{p} \leq 0,05$ sebagai batas kemaknaan statistik.

\section{HASIL}

Didapatkan 50 subjek yang mayoritas lakilaki $(70,0 \%)$, rerata umur $32,98 \pm 9,726$ tahun, dan sebanyak 46\% mengalami NP-HIV (Tabel 1 dan Tabel 2). Subjek dengan usia $<30$ tahun lebih banyak yang menderita NP $(\mathrm{p}=0,02)$. Walaupun tidak bermakna, seluruh subjek yang mendapat terapi stavudine mengalami neuropati (100\%). Gangguan kognitif tidak berhubungan dengan adanya neuropati. Namun saat dilakukan analisis untuk nilai IHDS, didapatkan adanya hubungan yang bermakna $(\mathrm{p}=0,04)$ antara nilai IHDS dengan neuropati perifer (data tidak ditampilkan).

Tabel 1. Karakteristik Subjek Penelitian $(n=50)$

\begin{tabular}{|c|c|c|c|}
\hline \multirow{2}{*}{ Variabel } & \multicolumn{2}{|c|}{ Neuropati n(\%) } & \multirow{2}{*}{$\mathbf{p}^{*}$} \\
\hline & Ya & Tidak & \\
\hline \multicolumn{4}{|l|}{ Jenis Kelamin } \\
\hline - Laki-laki & $18(51,4)$ & $17(48,6)$ & 0,24 \\
\hline - Perempuan & $5(33,3)$ & $10(66,7)$ & \\
\hline \multicolumn{4}{|l|}{ Umur } \\
\hline - $<30$ tahun & $6(27,3)$ & $16(72,7)$ & 0,02 \\
\hline - $\geq 30$ tahun & $17(60,7)$ & $11(39,3)$ & \\
\hline \multicolumn{4}{|l|}{ Pendidikan } \\
\hline - $\leq 9$ tahun & $4(50)$ & $4(50)$ & 1,00 \\
\hline - $>9$ tahun & $19(45,2)$ & $23(54,8)$ & \\
\hline \multicolumn{4}{|l|}{ Pekerjaan } \\
\hline - Tidak bekerja & $3(25)$ & $9(75)$ & 0,09 \\
\hline - Bekerja & $20(52,6)$ & $18(47,4)$ & \\
\hline \multicolumn{4}{|c|}{ Indeks massa tubuh } \\
\hline - $>18,5$ & $15(41,7)$ & $21(58,3)$ & 0,32 \\
\hline - $\leq 18,5$ & $8(57,1)$ & $6(42,9)$ & \\
\hline \multicolumn{4}{|l|}{ Durasi ARV } \\
\hline - $\leq 3$ bulan & $7(58,3)$ & $5(41,7)$ & 0,32 \\
\hline - $>3$ bulan & $16(42,1)$ & $22(57,9)$ & \\
\hline \multicolumn{4}{|c|}{ Pemakaian stavudine } \\
\hline - $\mathrm{Ya}$ & $3(100)$ & 0 & 0,09 \\
\hline - Tidak & $20(42,6)$ & $27(57,4)$ & \\
\hline \multicolumn{4}{|l|}{ Penggunaan ARV } \\
\hline - $\mathrm{Ya}$ & $18(41,9)$ & $25(58,1)$ & 0,22 \\
\hline - Tidak & $5(71,4)$ & $2(28,6)$ & \\
\hline \multicolumn{4}{|c|}{ Kepatuhan minum ARV } \\
\hline - $\mathrm{Ya}$ & $1(50)$ & $1(50)$ & 1,00 \\
\hline - Tidak & $22(45,8)$ & $26(54,2)$ & \\
\hline \multicolumn{4}{|l|}{ Fungsi kognitif } \\
\hline - Normal & $18(43,9)$ & $23(56,1)$ & 0,71 \\
\hline - Terganggu & $5(55,6)$ & $4(44,4)$ & \\
\hline
\end{tabular}

*Uji Chi-square; ARV: antiretrovirus.

Tabel 2 menunjukkan kelompok dengan kadar $\mathrm{Hb}$, jumlah CD4, dan skor IHDS yang rendah lebih berisiko menyebabkan neuropati secara bermakna $(\mathrm{p}=0,02,0,01$, dan 0,04$)$. 
Tabel 2. Karakteristik Hasil Pemeriksaan Laboratorium $(\mathbf{n}=\mathbf{5 0})$

\begin{tabular}{|c|c|c|c|c|}
\hline \multirow{3}{*}{ Variabel } & \multicolumn{2}{|c|}{ Neuropati } & \multirow{2}{*}{ Total } & \multirow{3}{*}{$\mathbf{p}$} \\
\hline & Ya & Tidak & & \\
\hline & $\operatorname{Mean} \pm 2 S D$ & $\operatorname{Mean} \pm 2 S D$ & $\operatorname{Mean} \pm 2 S D$ & \\
\hline Umur (tahun) & $34,5 \pm 8,64$ & $31,7 \pm 10,55$ & $33 \pm 9,73$ & 0,16 \\
\hline Tinggi $(\mathrm{cm})$ & $161,8 \pm 6,92$ & $162,4 \pm 8,76$ & $162,1 \pm 7,9$ & 0,7 \\
\hline Hemoglobin $(\mathrm{g} / \mathrm{dl})$ & $11,3 \pm 2,97$ & $13,1 \pm 2,06$ & $12,3 \pm 2,64$ & 0,01 \\
\hline $\operatorname{Albumin}(\mathrm{g} / \mathrm{dl})$ & $3,6 \pm 0,53$ & $3,8 \pm 0,44$ & $3,7 \pm 0,5$ & 0,07 \\
\hline $\mathrm{CD} 4\left(\mathrm{sel} / \mathrm{mm}^{3}\right)$ & $138,5 \pm 280,79$ & $188,4 \pm 158,1$ & $165,5 \pm 222,03$ & 0,01 \\
\hline Durasi ARV (bulan) & $27,6 \pm 36,54$ & $15,4 \pm 18,73$ & $21 \pm 28,69$ & 0,77 \\
\hline Skor IHDS & $10,9 \pm 0,75$ & $11,3 \pm 0,85$ & $11,1 \pm 0,82$ & 0,04 \\
\hline
\end{tabular}

ARV: antiretrovirus; IHDS: International HIV Dementia Scale.

Pemeriksaan BPNS paling banyak mengungkap kasus neuropati (40\%) dibanding DN4 (26\%), walaupun yang terbukti secara objektif adalah $34 \%$ berdasarkan ENG (Gambar 1). Pada pemeriksaan ENG tipe neuropati tersering adalah neuropati sensorik dengan kerusakan aksonal dan di ekstremitas bawah, yaitu nervus suralis (34\%). Adapun pada pemeriksaan motorik, nervus peroneus yang paling sering mengalami penurunan amplitudo (Tabel 3).

Tabel 3. Jenis Neuropati berdasarkan Elektroneurografi

\begin{tabular}{lc}
\hline Tipe Neuropati & n (\%) \\
\hline Menurut tipe saraf & \\
- Motorik dan sensorik & $11(5,5)$ \\
- Sensorik & $22(11)$ \\
Menurut patologi & \\
- Aksonal & $16(8)$ \\
- Demielinisasi & $9(4,5)$ \\
- Campuran & $1(0,5)$ \\
Menurut lokasi & \\
- Ekstremitas atas & $0(0)$ \\
- Esktremitas bawah & $14(7)$ \\
- Ekstremitas atas dan bawah & $3(1,5)$ \\
\hline
\end{tabular}

Hasil analisis multivariat dengan regresi logistik (Tabel 4) memperlihatkan bahwa pekerjaan menjadi faktor yang memengaruhi luaran neuropati $(\mathrm{p}=0,03$, IK 95\% 1,24-155,0). Subjek yang bekerja akan berisiko 13,9 kali mengalami neuropati dibanding yang tidak bekerja.

\section{PEMBAHASAN}

Mayoritas subjek adalah laki-laki dengan rerata usia dalam kelompok usia produktif. Hal ini

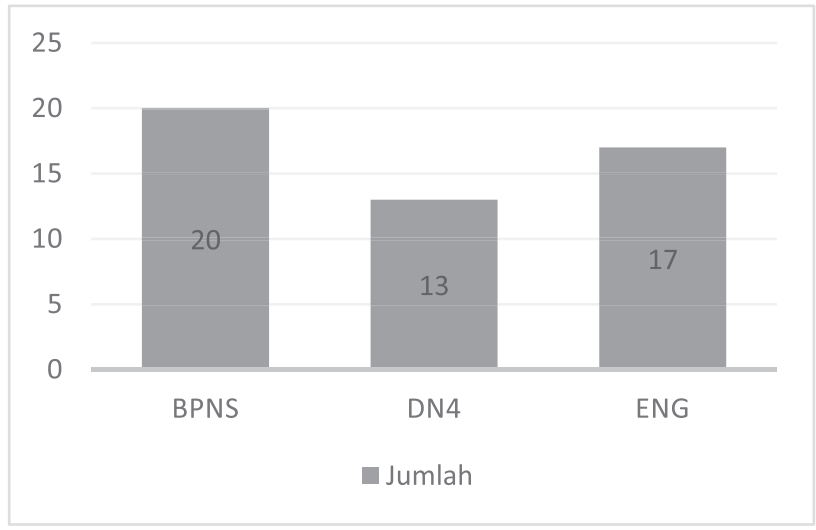

Gambar 1. Jumlah Subjek yang Terdiagnosis Neuropati

sesuai dengan data statistik kasus HIV/AIDS di Indonesia sampai Maret 2016, bahwa rasio laki-laki dibandingkan perempuan 1,7:1 dengan persentase usia tertinggi pada kelompok usia 20-39 tahun.

Rerata hitung sel CD4 dalam penelitian ini rendah, baik pada kelompok neuropati dan bukan neuropati. Demikian pula neuropati perifer ditemukan pada $46 \%$ kasus, lebih tinggi daripada rentang laporan temuan NP terkait HIV sebelumnya (19-42\%). Hal ini dapat disebabkan subjek yang diperiksa di poliklinik HIV/AIDS rata-rata telah berada dalam stadium klinis dan imunokompromais lanjut. Telah diketahui bahwa stadium klinis dan imunologis lanjut berhubungan dengan kejadian neuropati yang lebih tinggi. ${ }^{13}$

Penelitian di Afrika membuktikan risiko NP terkait HIV lebih tinggi pada penggunaan stavudine dibandingkan zidovudine setelah jangka waktu yang sama, ${ }^{11-12}$ sesuai dengan penelitian ini yang 
Tabel 4. Analisis Faktor-faktor yang Memengaruhi Neuropati

\begin{tabular}{lrrrrr}
\hline \multicolumn{1}{c}{ Variabel } & \multirow{2}{*}{ B } & \multirow{2}{*}{ Sig } & Eks(B) & \multicolumn{2}{c}{ IK 95\% } \\
\cline { 5 - 6 } & & & & Bawah & Atas \\
\hline Jenis Kelamin & $-0,80$ & 0,48 & 0,45 & 0,05 & 4,22 \\
Pekerjaan & 2,63 & 0,03 & 13,90 & 1,25 & 155,00 \\
Penggunaan stavudine & $-27,79$ & 0,10 & 0,00 & 0,00 &. \\
Umur & $-0,02$ & 0,63 & 0,98 & 0,89 & 1,08 \\
Hemoglobin & 0,56 & 0,11 & 1,76 & 0,87 & 3,53 \\
Albumin & $-0,21$ & 0,90 & 0,81 & 0,03 & 25,18 \\
CD4 & 0,01 & 0,08 & 1,01 & 0,10 & 1,01 \\
Skor IHDS & 0,50 & 0,34 & 1,66 & 0,58 & 4,70 \\
Penggunaan ARV & $-1,62$ & 0,25 & 0,20 & & 0,01 \\
Konstanta & $-9,44$ & 0,14 & 0,00 & & 3,13 \\
\hline
\end{tabular}

mendapatkan semua subjek yang mendapatkan stavudine mengalami neuropati. Pada penelitian ini, kebanyakan subjek menerima regimen tanpa stavudine dan atau zidovudine. Hal ini terkait dengan regimen ARV terbaru yang menghindari pemakaian stavudine dan zidovudine. Terbatasnya variasi obat ini mungkin yang menjelaskan tidak berpengaruhnya variabel penggunaan ARV pada penelitian ini. Kelompok subjek yang menggunakan stavudine semuanya mengalami neuropati dan yang tidak menggunakan stavudine ada $(42,6 \%)$ yang mengalami neuropati.

Usia menjadi faktor yang berhubungan dengan kejadian neuropati pada penelitian ini, sesuai dengan penelitian di Afrika, Asia, dan Australia adanya hubungan antara usia dan NP-HIV. Semakin tinggi usia maka kemampuan regenerasi saraf tepi makin berkurang. Selain itu, bertambahnya usia juga meningkatkan risiko timbulnya penyakit-penyakit lain yang dapat memberikan penyulit NP. ${ }^{14-15}$

Tinggi badan merupakan predisposisi terjadinya NP-HIV, yaitu semakin tinggi seseorang, semakin berisiko mengalami NP terkait HIV. Hal ini disebabkan neuropati merupakan suatu length dependent neuropathy. Walaupun demikian, penelitian ini tidak menemukan hubungan antara tinggi badan dengan NP, dapat disebabkan karena rerata tinggi badan subjek yang tidak begitu tinggi $(162,1 \pm 7,9 \mathrm{~cm})$, seperti halnya penelitian di Bali. ${ }^{3}$ Namun serabut saraf yang paling banyak terpengaruh dalam penelitian ini adalah nervus suralis dan nervus peroneus, yang mengindikasikan bahwa NP-HIV kebanyakan merupakan suatu length dependent neuropathy.

Kadar $\mathrm{Hb}$ yang rendah berhubungan dengan kejadian neuropati pada penelitian ini, sesuai dengan di Afrika bahwa kadar $\mathrm{Hb}$ yang rendah mungkin berperan sebagai faktor tambahan yang memperparah neuropati. ${ }^{15}$

Sel T CD4 merupakan target utama HIV, sehingga akan menurun sejalan dengan perkembangan infeksi HIV menjadi AIDS. Jumlah set T CD4 merupakan parameter status imunologis pasien HIV/ AIDS. Penelitian ini mendapatkan jumlah CD4 yang rendah berhubungan dengan kejadian neuropati secara bermakna, seperti penelitian lain., ${ }^{3,16}$

Gangguan kognitif tidak berhubungan secara bermakna dengan neuropati dalam penelitian ini. Namun, skor IHDS yang lebih rendah secara bermakna lebih banyak ditemukan pada subjek dengan neuropati yang memerlukan penelitian lebih lanjut.

Pada penelitian ini terlihat bahwa variabel bekerja berhubungan secara bermakna dengan kejadian NP-HIV dibandingkan tidak bekerja. Namun demikian, variabel ini masih menjadi kontroversi jika dihubungkan dengan kejadian NP terkait HIV yang tidak ditemukan dalam beberapa penelitian sebelumnya. Mawuntu dkk, di Jakarta menemukan tidak ada hubungan antara faktor bekerja atau tidak bekerja dengan neuropati. ${ }^{17}$ Namun Philomene dkk di Afrika memperlihatkan bahwa subjek yang bekerja lebih banyak yang mengalami neuropati perifer terkait HIV. ${ }^{12}$ 
Faktor pekerjaan repetitif sudah dicoba untuk dieksklusi dalam penelitian ini sehingga kemungkinan NP terkait HIV tidak disebabkan oleh jenis pekerjaan. Bekerja berhubungan dengan adanya aktivitas fisik harian yang lebih sering dibandingkan dengan tidak bekerja, termasuk berjalan dan mengendarai sepeda motor. Gerakan maupun penekanan pada saraf yang terus menerus menyebabkan iskemik dan edema pada endoneural yang menyebabkan demielinisasi. Proses demielinisasi ini bisa diikuti dengan kerusakan akson..$^{18} \mathrm{Hal}$ ini menjelaskan adanya faktor bekerja dengan NP-HIV pada penelitian ini.

Diagnosis neuropati dalam penelitian ini terbanyak menggunakan BPNS. BPNS sebenarnya memiliki nilai sensitivitas dan nilai prediksi positif yang tidak terlalu tinggi, yaitu $49 \%$ dan $72 \%$. Meskipun demikian, neuropati yang ditemukan dengan pemeriksaan ini sudah mencapai $46 \%$. Hal ini mengonfirmasi dugaan masalah NP terkait HIV di Manado sementara, yang sebenarnya lebih besar daripada prevalensi NP-HIV di seluruh dunia.

Pemeriksaan ENG mampu menemukan 34\% kasus NP dalam penelitian kami. Temuan ini memang masih lebih rendah dibanding BPNS. Namun demikian terdapat 3 subjek dengan penurunan amplitudo pada pemeriksaan ENG BPNS normal. Lebih rendahnya temuan neuropati dengan ENG disebabkan oleh adanya NP yang melibatkan serabut saraf kecil yang pada fase awal dapat menunjukkan hasil yang normal pada pemeriksaan ENG. ${ }^{11}$ Penelitian yang dilakukan Philomene dkk, yang menggunakan pemeriksaan ENG ditemukan 27\% subjek menunjukkan kelainan ENG tanpa gejala klinis. ${ }^{12}$

Banyak informasi yang bisa diperoleh dari pemeriksaan ENG meskipun sensitivitasnya tidak setinggi BPNS, yaitu bahwa tipe neuropati tersering adalah tipe sensorik dengan tipe aksonal di ekstremitas bawah. Serabut sensorik yang lebih tipis umumnya lebih rentan mengalami neuropati metabolik dibandingkan serabut saraf motorik. Patologi kerusakan saraf tipe aksonal memang merupakan salah satu ciri patologi NP terkait HIV. ${ }^{13-14}$

Keterbatasan penelitian ini adalah tidak dikerjakan biopsi untuk konfirmasi diagnostik serta pemeriksaan mTNS juga tidak dikerjakan karena ketiadaan alat. Namun demikian pemeriksaan ENG tetap dikerjakan. Penelitian ini juga bersifat potong lintang sehingga perlu dilanjutkan dengan desain penelitian kohort untuk melihat perubahan variabel terhadap waktu.

NP terkait HIV perlu mendapat perhatian yang lebih besar dalam penatalaksanaan pasien. Pemeriksaan penyaring cukup baik untuk menemukan kasus. Informasi tambahan adalah kepatuhan minum obat subjek sangat rendah yang perlu mendapat perhatian, karena dapat meningkatkan risiko resistensi obat.

\section{KESIMPULAN}

Didapatkan prevalensi NP-HIV yang cukup tinggi dengan dipengaruhi oleh usia $\geq 30$ tahun serta kadar hemoglobin, CD4, dan skor IHDS yang rendah. Faktor bekerja meningkatkan kecenderungan 13,9 kali mengalami NP terkait HIV.

\section{DAFTAR PUSTAKA}

1. Lestari L, Widyadharma P, Merati K. Uji reliabilitas dan validitas modifikasi neuropathic pain diagnostic questionnaire terhadap leeds assesment neuropathic symptoms and sign pada pasien HIV/AIDS. Neurona. 2013;30(4):229-33.

2. Widjaja H, Widyadharma P, Merati T. Uji reliabilitas brief peripheral neuropathy screen. Neurona. 2014;31(3):142-7.

3. Widyadharma E. Factors that correlate with neuropathic pain in HIV/AIDS patient at Sanglah Hospital. Researchgate. 2015;2015:6(5):255-7.

4. Cherry C, Wadley A, Kamerman P. Diagnosing and treating HIV-associated sensory neuropathy: a global perspective. Pain Manag. 2016;6(2):191-9.

5. Schutz S, Robinson J. HIV-related neuropathy: current perspectives. HIVAIDS-Res Palliat Care. 2013;5:243-51.

6. Merkies I, Faber C, Lauria G. Advances in diagnostic and outcome measures in peripheral neuropathies. Neurosci Lett. 2015;596:3-13.

7. Cettomai D, Kwasa J, Birbeck G, Price R, Cohen C, Bukusi E, dkk. Screening for HIV-associated peripheral neuropathy in resource-limited settings. Muscle Nerve. 2013;48(4):516-24.

8. Ditjen PP, PL Kemenkes RI. Statistik Kasus HIV AIDS di Indonesia. 2016.

9. Kementrian Kesehatan RI. Estimasi dan proyeksi HIV/AIDS di Indonesia tahun 2011-2016. 2013.

10. Meyer A. Neurology and the global HIV epidemic. 
Semin Neurol. 2014;34(1):70-7.

11. Kokotis P, Schmelz M, Papadimas G, Skopelitis E, Aroni K, Kordossis T, dkk. Polyneuropathy induced by HIV disease and antiretroviral therapy. Clin Neurophysiol. 2013;124(1):176-82.

12. Philomene K, Thierry A, Landry O, James I, Yvonne A, Martine M, dkk. Distal sensory polyneuropathy among HIV patients in Libreville in Gabon. Neurosci Med. 2015;6(03):84-9.

13. Centner C, Baterman K, Heckmann J. Manifestations of HIV infection in the peripheral nervous system. Lancet Neurol. 2013;12(3):295-309.

14. Amruth G, Kumar P, Nataraju B, Nagaraja B. HIV associated sensory neuropathy. J Clin Diagn Res. 2014;8(7):MC04-7.

15. Dubey T, Raghuvanshi S, Sharma H, Saxena R. HIV-neuropathy in pre-HAART patients and it's correlation with risk factors in central India. Neurol India. 2013;61(5):478-80.

16. Giubelan L, Cupsa A, Dunitrescu F, Niculescu I, Syoian A. Considerations about risk factors for peripheral neuropathies in Romanian HIV-infected patients. Curr Health Sci J. 2014;40(1):42-6.

17. Mawuntu A, Mahama C, Khosama H, Estiasari R, Imran D. Early detection of peripheral neuropathy using stimulated skin wrinkling test in HIV infected patients: a cross sectional study. InPress. 2015.

18. Mendoza J, Salgado A. Compression neuropathies. Dalam: Souayah N, editor. Peripheral neuropathy-a new insight into the mechanism, evaluation and management of a complex disorder. Croatia: InTech; 2013. h. 103-24. 